\title{
制振材料を用いた床衝整音低減に関する研究 その?：ツーバイフォー住宅における制振材料の床への貼付効果
}

末吉修三，大野進一，塩田正純，山口道征 115

福島寬和 [建設省建築研究所 第 5 研究部防煙研究室長 ·工博]

本論文では，制振材料による床衝撃音遮断性能（对重量衝撃源） の向上効果を, 木造建屋で検討した結果が報告されている。些細な ことではあるが, 若干私見を述べさせていただきたい。図 9〜図 12 の振動速度スペクトルに着目すると, モルタルだけの結果（実線） には, $45 \mathrm{~Hz}(63 \mathrm{~Hz}$ 帯域下端周波数) 付近に床構造の固有振動モード によるものと思われるピークが見られる。制振材料の施工により， このピーク周波数が $31.5 \mathrm{~Hz}$ 带域内へ移行している。これは, 制振材 料の質量分だけ，面密度が上昇したこと（質量効果）が主因ではな いかと思われる。四 13 や図 14 において $63 \mathrm{~Hz}$ 带域の床衝撃音レべ ルが, 制振材料の施工により大きく低下しているが, 上述のピーク 周波数の変化もかなり影響しているように思之る。勝手な考察をさ せていただいたが, 制振材料を用いた床衝撃音低減工法の開発は, 近年精力的に行われており, 兟越ながら, 今後も貴重な研究成果を ご報告いただければと思う次第である。
山下恭弘 [信州大学社会開発工学科 教授・工博] 木造床の重量床衝撃音低減は, これまでにもいろいろな試みがな されているが, 決定的な解決策がないのが現状であろう。一方, コ ンクリート系構造の集合住宅は，床厚さを $250 \mathrm{~mm}$ 程度にして L-50 を達成させるのが首都圏では常識になりつつある。単純に計算して $250 \mathrm{~mm}$ 床の面密度は, 約 $550 \mathrm{~kg} / \mathrm{m}^{2}$ であるのに対し, 木造床はその 1/10 以下が一般的であり, ほとんどが L一75 前後である。本報告は, 制振材料を用いて休衝撃音を低減させる研究を組織的，計画的にな された一連の報告である。37 $\mathrm{mm}$ 厚のモルタルとほぼ同程度の厚さ, 重量の非拘束タイプの制止材料を張り付けることにより，L-60を 達成している。重量比でRC 床の約 $1 / 4$ であるので, L一60 以下にな らないのは, RCの曲げ岡性, 床のインピーダンスなどと同等になっ ていないためであろう。振動加速度, 損失係数と床衝撃音の関係を 明らかにするまでに至っていないところは, 私を含めて研究者とし て共通の悩みであろう。今後の研究成果を期待したい。
酒井寞二 [(株)大林組技術研究所 副所長・工博 $]$ 建物床下二重スラブは, 蓄熱水槽としての利用例は多かったが, 本報告のような取り入れ外気予冷熱利用は貴重な先導的実施例であ る。土裹の蓄熱利用に当たっては, 熱交換装置コストがネックとな るが, 建物の条件次第で今後も適用される機会は多いと推定される。 各種実測値の整理や数值計算法の検討は入念に試され，今後第 3 者が実際の計画に利用できるよう配慮されているが, 幾つか疑問点 を感じた。すなわち, 床下二重スラブ内部は, 一般に湧水が漏出し て湿鬥状態に有り, 取り入れ外気が加湿される傾向があるが, 報告 の中ではこの点に触れられていない。また，長期にわたる空気流通 で特殊な菌類が増殖し，人体に有害であったり悪臭の原因となる恐 れはないのであろうか。また, 室内床面からの熱移動は冬季に室内 環境を著しく悪くするので, 床断熱は不可久であろうが, コストを 含めた総合的なメリットがあるシステムであろうか, 今後更なる検 討を深めて頂きたい。
佐藤真奈美 [大阪工業大学建築学科 講師・博士 (工学)] 本報告のシステムは地下ピットの躯体と地盤を取り入れ外気の一 次処理を行う恒温熱源として利用した簡易な省エネルギー設備で す。測定結果に示されるように地盤への熱的負担が少なく, 熱容量 に見合った設備であり長期にわたる省エネルギー効果が期待されま す。省エネルギー効果を子測するための解析は，このシステムが外 乱の影響が大きく複雑な流れの経路を持つので極めて煩雑なもので す。しかし，この効果 (外気負荷軽減効果)の予測が単純な 2 次元熱 移動モデルで行えることを示したことは設計法の観点から評価出来 るものと考之ます。

著者らが挙げているコンクリートや地盤の水分移動の影響に関す る今後の検討はこのシステムの予測精度を上げるために極めて重要 となりましょう。さらに，地下ピット内で発生する結露を原因とす る熱交換された取り入れ空気の質に関する問題や，取り入れ空気の 除湿などによる外気負荷軽減効果等を定量的に示して下さることを 期待します。

\section{季節別の太陽高度の変化を利用した日射制御空の開発 その 1. 日射制御空の概要と性能予測}

宇田川光弘 [工学院大学建築学科教授. 工博] 本報告は，空の日射制缻についての技術開発の成果を述べたもの である。直達日射は夏季には遮蔽し, 冬季には室内への導入が望ま しく, 南面の庇はそのような日射制御機能を備えていることが知ら れているが，庇が設置できない場合も多い。空がラス自体での日射 制御機能が可能となれば, 適用の範囲は広く, 日射と昼光の制御に よる熱負荷，照明負荷の低減が可能になると思われる。

ここでは複層がラスの利用を前提に，ガラスに熱線反射膜を水平 に線状にコーティングする方法を提案しているので，太陽位置との 関係から目的に合わせた日射遮蔽効果を選択することができる。本 報告では, 方位や季節に適した, 2 枚のガラスでの水平線上コーティ ングの配置をシミュレーションにより検討し，それぞれの適切な構 成を提案できることを示している。奏用化には, 視環境への影響な ども含めた実験, 実測による検討が必要であるが,これについては, 続報での報告を期待したい。
石野久骊 [東京都立大学工学研究科建築学専攻 教授・工博] 本研究はちょっとしたアイデアから発想された面白い研究であ る。図一1のプロファイル角の日変化, 年変化などグラフで見るのは 初めてのことで興味梁い。このことから遮蔽したい日射と取得した い日射に分けることに目をつけて，南面では概ねプロファイル角 $50^{\circ}$ を境界と判断して, ガラス上に水平ストライプコーティングする ことを提案している。また西面では $40^{\circ}$ 以下のプロファイル角に対 して日射透過率を小さくすると, 西日による暑熱感の軽減ができる としている。この結果, 各地域における日射制御目的に応じて, そ の可変パラメータ（複層がラスの間隔, 反射膜ストライプの寸法, 反射率）を変化させることにより，目的の性能が得られるとしてい る。

私の予想では提案されたストライプのとき室内からの景観は，ほ とんど害されないと思えるが,このことに対するコメントがあって もいいのではないでしょうか。 